\title{
gemcitabine-docetaxel versus gemcitabine - cisplatin as first-line therapy in patients with advanced non-small cell lung cancer
}

\author{
Samy M. Al-Gizawy and Hanan G. Mostafa \\ Department of Clinical Oncology, Faculty of Medicine, Assiut University
}

\begin{abstract}
Purpose: was to compare the gemcitabine-docetaxel combination with the standard cisplatin- gemcitabine regimen in patients with advanced or metastatic Non-small cell lung cancer (NSCLC) in a phase III study. Patients and Methods: From Nov. 2010 to Jun. 2013, all patients with TNM stage IIIB or IV NSCLC who met the eligibility criteria were enrolled in this study. They were randomized into two arms: Arm 1 (gemcitabinecisplatin (GC) arm) and Arm 2 (gemcitabine-docetaxel (GC) arm). In both arms, gemcitabine was administered at the dose of $1000 \mathrm{mg} / \mathrm{m} 2$ on days 1 and 8 every 21 days. In GD Arm, docetaxel $75 \mathrm{mg} / \mathrm{m} 2$ was administered intravenously on day 1 . In GC Arm, cisplatin $75 \mathrm{mg} / \mathrm{m} 2$ was administered intravenously on day 1 . Patients with stable disease (SD) received a maximum of six cycles; and patients with a complete response or partial response (PR) after the sixth cycle received 2 additional cycles.

Results: Ninety one patients were enrolled in this study, of which 45 and 46 were randomized to the GC and GD arms, respectively. The median progression free survival (PFS) was 6.5 months for GD arm vs. 6.8 months for GC arm, $(P=0.772)$. Median Overall survival (OS) was 8.5 months for the GD group and 8.9 months for the GC group, $(P=0.945)$. There was also no difference in OS between the two treatment arms with regards the primary stratification factor of histology $(P=0.922)$. No CR cases were recorded in either group. PR rate was $43.5 \%$ in the GD arm compared with $46.7 \%$ patients in the GC arm.

Chemotherapy-related toxicities including hematologic, nausea and vomiting and nephrotoxicity were more common in the GC group. There were no toxicity-related deaths.

Conclusion: The results presented in this study suggest that gemcitabine-docetaxel (GD) combination is equally active to standard cisplatin-gemcitabine (GC) regimen when used as first-line therapy in the treatment of patients with stage IIIB/IV NSCLC. The more favorable toxicity profile of GD supports its use as first-line chemotherapy, especially in patients who cannot tolerate cisplatin.
\end{abstract}

Key words: advanced non-small cell lung cancer, chemotherapy, cisplatin and docetaxel Corresponding Author: Hanan Gamal El-deen Mostafa

E-mail: mostafahanan36@yahoo.com

\section{INTRODUCTION}

Lung cancer is the leading cause of cancer deaths worldwide in men, and second most common in women. Worldwide, lung cancer occurred in approximately 1.8 million patients in 2012 and caused an estimated 1.6 million deaths ${ }^{1}$. Non-small-cell

lung cancer (NSCLC) represents more than $80 \%$ of lung cancer diagnoses and has an overall 5-year survival rate of approximately $16 \%$, which decreases precipitously among patients diagnosed with late stage disease ${ }^{2}$.

Despite enthusiasm for the use of molecular testing and molecularly targeted agents in patients with advanced non-small cell lung cancer (NSCLC), most patients are not candidates for upfront treatment with molecular agents. Moreover, many candidate patients can't afford the vastly increased cost of such novel agents. Chemotherapy therefore remains the first-line treatment for most patients with stage IV non-small cell lung cancer (NSCLC) ${ }^{3}$.

Multiple individual randomised studies and several meta-analyses have shown a survival benefit for platinumbased chemotherapy compared with best supportive care in patients with good performance status $\mathrm{s}^{4,5}$, but at the cost of severe toxicities. Combinations with better toxicity profile but with equal or improved efficacy are eagerly needed. Nonplatinum combinations have been tested and are considered alternative regimens for those who cannot tolerate platinum-based chemotherapy. Among these combinations, the combination of gemcitabine and docetaxel has emerged as one of the most promising, showing equivalent efficacy with, and less toxicity than, cisplatin-based chemotherapies ${ }^{6}$. 


Vol. 10 | No. 1-2 $2014 \quad$ Samy M. Al-Gizawy and Hanan G. Mostafa

Gemcitabine (2'-deoxy-2',2'-difluorocytidine monohydrochloride) is a nucleoside antimetabolite against deoxycytidine. It is intracellularly metabolized to gemcitabine triphosphate, which inhibits DNA synthesis, and has shown potent cytocidal activity against solid tumors ${ }^{7}$. Docetaxel, an antineoplastic agent that acts on microtubules to promote formation of abnormal microtubule bundles, has also shown cytotoxicity ${ }^{8}$. Gemcitabine and docetaxel have different mechanisms of action, but by combining them, there is the potential of synergistic antitumor activity ${ }^{9}$.

Aim of the study was to compare the gemcitabinedocetaxel combination with the cisplatin- gemcitabine regimen as first-line therapy in patients with advanced or metastatic NSCLC in a phase III study.

\section{PATIENTS AND METHODS}

Between Nov. 2010 till Jun. 2013, patients with stage IIIB or IV NSCLC presenting at Assiut University Oncology Department were entered in this prospective phase III randomized trial. Sample size was based on the prevalence of advanced NSCLC in Assiut Clinical Oncology department. An accrual rate of 45 patients/year was projected and a total sample size was 90 patients.

\section{Eligibility Criteria}

Patients with histologically or cytologically confirmed unresectable TNM stage IIIB or IV NSCLC (according to AJCC cancer staging system 7th edition (2010)) who met the following criteria were eligible for the study: with no prior chemotherapy; with at least one measurable lesion that could be accurately measured in at least one dimension; aged 20-74 years; Eastern Cooperative Oncology Group (ECOG) performance status of 0-2; a life expectancy of at least 3 months; and adequate organ functions as indicated by white blood cell count $\geq 4.0$ $\times 109 / 1$, platelets $\geq 100 \times 109 / 1$, hemoglobin $\geq 9.5 \mathrm{~g} / \mathrm{dl}$, aspartate aminotransferase/alanine aminotransferase $\leq 2.5$ times the upper limit of normal, total bilirubin $\leq 1.5$ times the upper limit of normal, serum creatinine $\leq$ the upper limit of normal.

Patients were excluded from the study if they had radiologically and clinically apparent interstitial pneumonitis or pulmonary fibrosis, or grade 2-4 peripheral neuropathy or marked edema. Additional exclusion criteria included: superior vena cava syndrome; symptomatic brain metastasis; or history of serious drug allergy.

All patients who entered into this study were required to give written informed consent. The trial was approved by the ethics committee of the Faculty of Medicine, Assiut University.

\section{Study Design and Treatment}

Patients were randomized by simple randomization into two arms: Arm 1 (GC arm) and Arm 2 (GD arm). In both arms, gemcitabine was administered at the dose of $1000 \mathrm{mg} / \mathrm{m}^{2}$ in a $30-\mathrm{min}$ infusion on days 1 and 8 every 21 days. In GD Arm, docetaxel $75 \mathrm{mg} / \mathrm{m}^{2}$ was administered intravenously over at least $1 \mathrm{~h}$ on day 1 . Gemcitabine was given immediately after the docetaxel infusion. In GC Arm, cisplatin $75 \mathrm{mg} / \mathrm{m}^{2}$ was administered intravenously over $2 \mathrm{~h}$ on day 1 . All patients received ondansetron $8 \mathrm{mg}$ and dexamethasone $8 \mathrm{mg}$ intravenously as premedication. Those receiving docetaxel received dexamethasone $8 \mathrm{mg}$ orally BID the day before, and the day after and 12 hours after docetaxel infusion. Those receiving cisplatin were prehydrated with $1000 \mathrm{~mL}$ NS over 1 hour, then given Cisplatin IV in $500 \mathrm{~mL}$ NS with $20 \mathrm{mEq}$ potassium chloride, $1 \mathrm{~g}$ magnesium sulfate, $30 \mathrm{~g}$ mannitol over 2 hours.

Patients with stable disease (SD) received a maximum of six cycles; and patients with a complete response or partial response (PR) after the sixth cycle received 2 additional cycles.

\section{Dose Modifications}

Administrations of chemotherapeutic drugs on day1 were delayed for patients with an absolute neutrophil count $<1.5 \times 109 / 1$, a platelet count $<100 \times 109 / 1$, or any grade $3 / 4$ non-hematologic toxicities. When gemcitabine was given on day 8 of both arms, exceptions included leukopenia $<2.0 \times 109 / 1$ and an absolute neutrophil count $<1.0 \times 109 / 1$, a platelet count $<70 \times 109 / 1$, or any grade $3 / 4$ non-hematological toxicities. In subsequent cycles, doses of both drugs of both arms were reduced by $25 \%$ if chemotherapy-induced febrile neutropenia or grade 4 thrombocytopenia occurred. The doses of docetaxel and cisplatin were reduced by $25 \%$ for grade 2 or 3 neurotoxicity. Dose reductions were maintained for all subsequent cycles.

\section{Baseline and Treatment Assessment}

Before the day of starting the study treatment, assessments at baseline included doing physical examination in addition to history taking, grading performance status, tumor measurements by chest X-ray and computed tomography (CT) scan of the neck, chest and abdomen, and doing $\mathrm{CBC}$, blood chemistries, creatinine clearance and electrocardiography (ECG). Bone scan and MRI brain were also done for all patients.

Assessment of patients' complaints, performance status, physical examination, hematology, and blood chemistries were obtained days 1 and 8 of each cycle. Adverse events were estimated according to National Cancer Institute-Common Toxicity Criteria version 2.0. 
Kasr-El-Aini Journal Of Clinical Oncology And Nuclear Medicine

Vol. 10 | No. 1-2 2014

gemcitabine-docetaxel versus gemcitabine - cisplatin as first-line...

Lesions were measured after 1 st cycle by chest $\mathrm{x}$-ray and each cycle if they were assessable by physical examination. All patients were evaluated by computed tomographic scans of the chest and abdomen after every three courses.

Standard WHO response criteria ${ }^{10}$ were used to define the tumor response. A complete response (CR) required the disappearance of all measurable and assessable disease in all disease sites, including no new lesions. A partial response $(\mathrm{PR})$ required $\geq 50 \%$ decrease in the sum of the products of the perpendicular diameters of all measurable lesions. Both CR and PR had to be maintained for more than 4 weeks. Stable disease was defined as a decrease of less than $50 \%$ as well as an increase of less than $25 \%$ in the sum of the products of measurable lesions without the appearance of any new lesion. Progressive disease was defined as an increase of $\geq 25 \%$ in the sum of the products of the measurable disease or the appearance of any new lesions or the reappearance of any lesion that had disappeared. Patients with disease progression, either primary or after initial response were assessed for ECOG PS and organ functions. Those who still had ECOG PS $\leq 2$ and adequate organ functions were offered 2 nd line single agent chemotherapy (carboplatin AUC 5 for Arm 1 patients and Docetaxel $75 \mathrm{mg} / \mathrm{m}^{2}$ for Arm 2 patients). Other patients received best supportive care.

The primary objective of the study was to compare overall survival (OS); secondary objectives included evaluation of response rates, progression-free survival (PFS), and toxicity on both study arms.

\section{Statistical methods of analysis:}

Overall survival and progression free survival were estimated by Kaplan Meier methods. Overall survival was estimated from the date of treatment start till death or last follow-up visit. Progression-free survival (PFS) was defined as the time elapsed between treatment initiation and tumor progression or death from any cause.

Tests of significance: $\mathrm{T}$ test and Chi-square were used to study significance differences between variables.

$* P$.value $>0.05$ not significant. $* P$. value $\leq 0.05$ significant.

Statistical analysis was performed using SPSS for Windows version 20.0 (SPSS, Inc., Chicago, IL).

\section{RESULTS}

From Nov. 2010 to Jun. 2013, 91 patients were enrolled in this study, of which 45 and 46 were randomized to the GC and GD arms, respectively. Patient demographics and clinical characteristics are presented in
Table 1. Both arms were balanced for age, sex, smoking habits, disease stage, and histologic subtype and grade. Of the whole series, more than $80 \%$ of patients had stage IV disease. The most common histologic subtype was adenocarcinoma (GD, 53.3\% and GC, 54.3\%).

Overall, 37 of 91 patients (40.7\%) completed the six cycles of treatment (GD, 17/45 [37.8\%] and GC, 20/46 [43.5\%]). Another 31 patients received only four cycles of chemotherapy (GD, 14/45 [31.1\%] and $\mathrm{GC}, 17 / 46[37 \%])$. The remaining patients received a range of 1-3 cycles (GD, 14/45 [31.1\%] and GC, 9/46 [19.6\%]). The main cause of treatment withdrawn was progression of disease (28.9\% and $30.4 \%$ in arm GD and GC respectively) while early stopping for serious adverse events occurred in $10.9 \%$ and $17.6 \%$ in arm GD and GC, respectively. In arm GD, $33.3 \%$ of cycles were delayed for haematological or nonhaematological toxicities and in $16.7 \%$ of the cycles the doses of both drugs were reduced. In arm GC treatment was delayed in $26.7 \%$ of cycles with dose reduction of both drugs in $17.5 \%$ of cycles.

\section{Outcome}

With a median follow-up 17 months, the median PFS was 6.5 months (S.D. $=0.472(5.5757 .425-))$ for GD group and 6.8 months (S.D. $=0.302(6.2087 .392-)$ ) for GC group (Figure 1). There was no statistically significant difference in PFS between the two treatment arms $(P=0.772)$. Median OS was 8.5 months (S.D. $=$ $0.421(7.6479 .326-))$ for the GD group and 8.9 months $($ S.D. $=0.674(7.58010 .220-)$ ) for the GC group, $(P=0.945)$ (Figure 2).

With stratifying patients according to the histopathological diagnosis into squamous and nonsquamous subgroups, there was also no difference in OS between the two treatment arms (Fig. 3 A \& B) $(P=$ 0.922).

No complete response cases were recorded in either group. Partial response rate was $43.5 \%$ in the GD group compared with $46.7 \%$ patients in the GC group (Table 2).

Only 9 patients $(20 \%)$ of GD group and 8 patients (17.4\%) of GD group received second-line chemotherapy. Other patients received best supportive care on disease progression.

\section{Toxicity}

A summary of grade $3 / 4$ toxicities by treatment arm is presented in Table 3. The most common grade 3/4 toxicities were hematologic in nature, with thrombocytopenia, neutropenia, and leukopenia being more prevalent in GC Arm than in GD Arm but the differences are not statistically significant. Vomiting 
(17.6\% and $10.9 \%$ for GC and GD, respectively) was the most common nonhematologic grade $3 / 4$ toxicities. Grade 3/4 peripheral sensory neuropathy occurred at a higher rate in the GD group than in the GC group $(8.7 \%$ versus $4.4 \%$ ). There was no toxicity-related death.

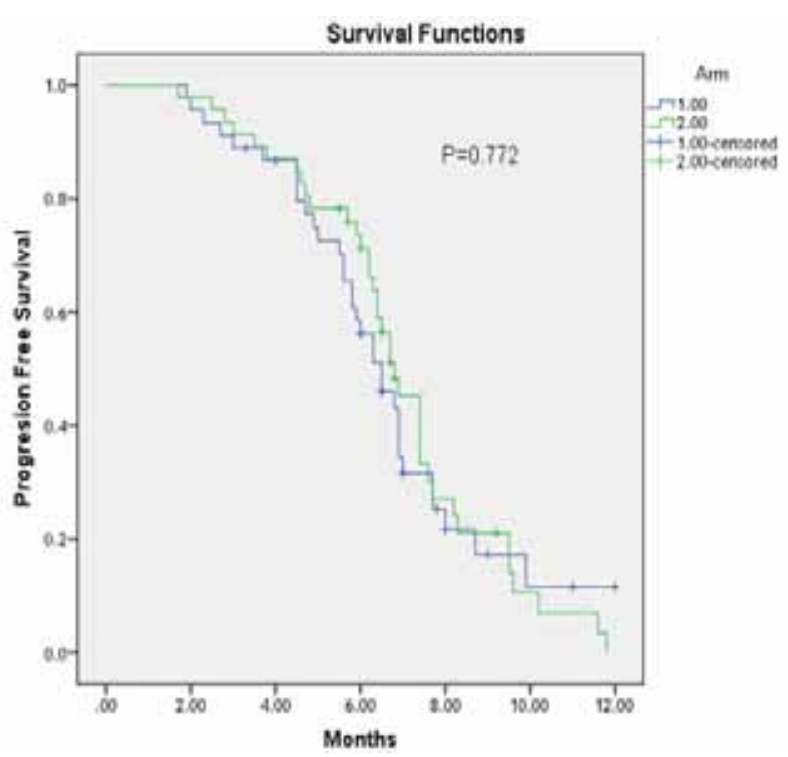

Figure 1: Progression-free survival (PFS) of patients with stage III\& IV advanced non-small cell lung cancer treated by gemcitabine-cisplatin (arm 1, 45 patients) $\mathrm{PFS}=6.8$ months and the other arm treated by gemcitabine-docetaxel (arm 2, 46 patients) $\mathrm{PFS}=6.5$ months (log-rank $P=0.772)$.

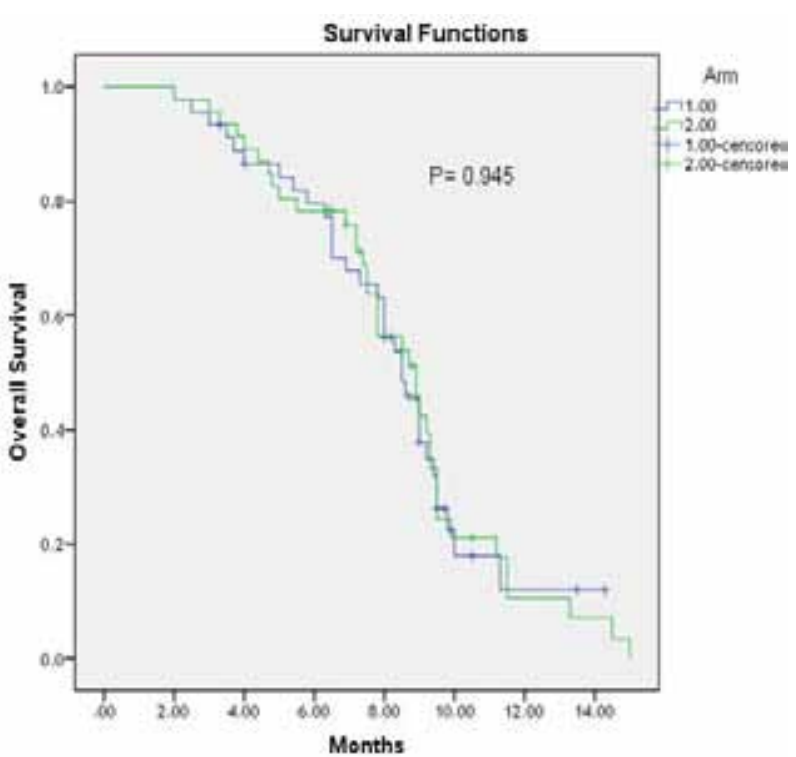

Figure 2: Overall survival (OS) of patients with stage III\& IV advanced non-small cell lung cancer treated by gemcitabinecisplatin (arm 1, 45 patients) median OS was 8.9 months and the other arm treated by gemcitabine-docetaxel (arm 2, 46 patients), median OS was 8.5 months (log-rank $P=0.945$ ).

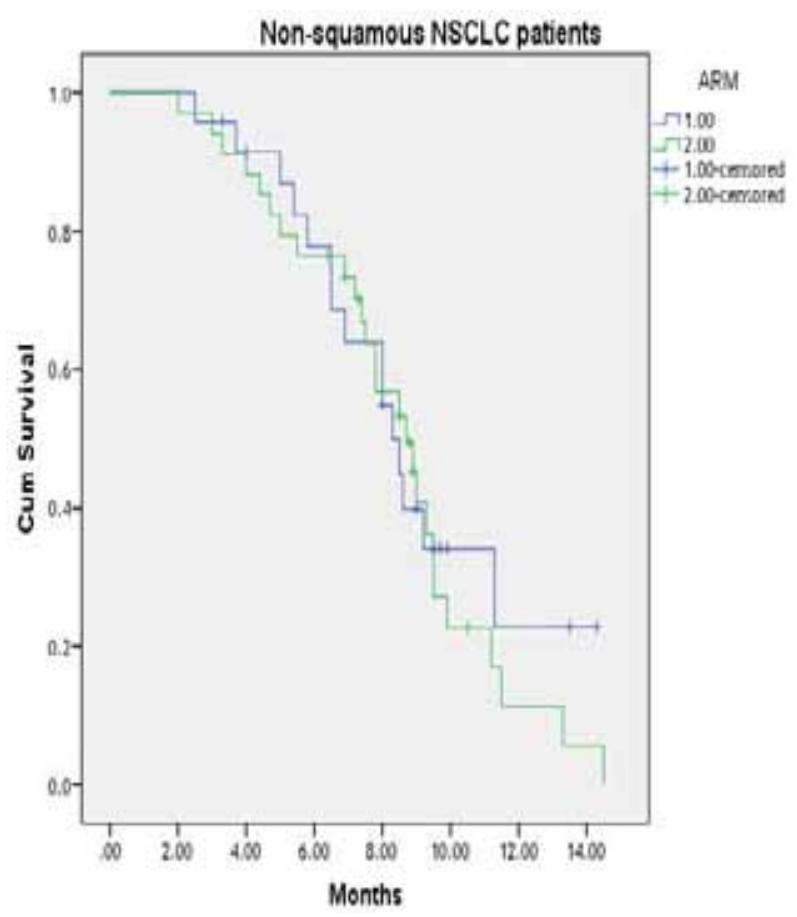

Figure 3-A. Overall survival of patients with non-squamous histology in arm $1(\mathrm{No}=28)$ treated by gemcitabine-cisplatin and $\operatorname{arm} 2(\mathrm{No}=31)$ treated by gemcitabine-docetaxel, $P=0.922$.

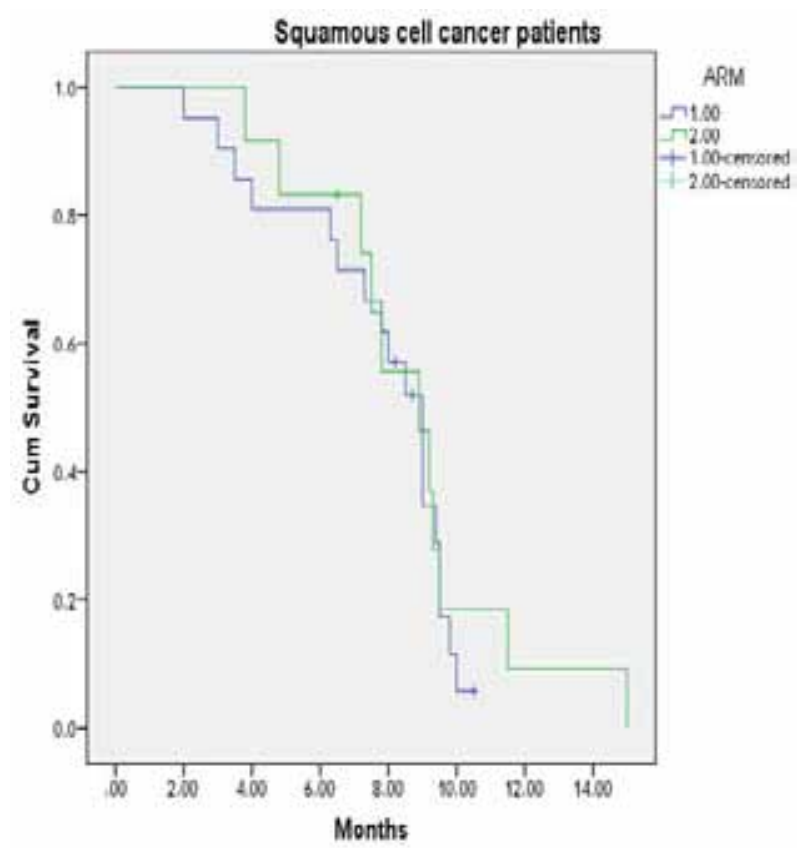

Figure 3-B. Overall survival of patients with squamous histology in arm $1(\mathrm{No}=17)$ treated by gemcitabine-cisplatin and arm $2(\mathrm{No}=15)$ treated by gemcitabine-docetaxel, $P=0.92$. 
Table 1: Patient demographics and clinical characteristics.

\begin{tabular}{|c|c|c|c|}
\hline Item & $\begin{array}{c}\text { Arm } 1 \\
(\mathrm{GC} \text { patients }=45) \\
\text { No. }(\%)\end{array}$ & $\begin{array}{c}\text { Arm } 2 \\
(\text { GD patients=46) } \\
\text { No. }(\%)\end{array}$ & $\boldsymbol{P}$-value \\
\hline $\begin{array}{l}\text { Age "years" } \\
\text { Median } \\
(\min -\max )\end{array}$ & $\begin{array}{c}64 \\
(37.0-73.0)\end{array}$ & $\begin{array}{c}60 \\
(42.0-74.0)\end{array}$ & 0.780 \\
\hline $\begin{array}{l}\text { Sex: } \\
\text { Female } \\
\text { Male }\end{array}$ & $\begin{array}{c}14(31.1 \%) \\
31(68.9 \%)\end{array}$ & $\begin{array}{l}15(32.6 \%) \\
31(67.4 \%)\end{array}$ & 0.529 \\
\hline $\begin{array}{l}\text { Smoking: } \\
\text { Non-smokers } \\
\text { Smokers }\end{array}$ & $\begin{array}{l}18(40 \%) \\
27(60 \%)\end{array}$ & $\begin{array}{l}16(34.8 \%) \\
30(65.2 \%)\end{array}$ & 0.425 \\
\hline $\begin{array}{l}\text { ECOG PS: } \\
0 \\
1 \\
2\end{array}$ & $\begin{array}{l}18(40.0 \%) \\
17(37.8 \%) \\
10(22.2 \%)\end{array}$ & $\begin{array}{l}16(34.8 \%) \\
20(43.5 \%) \\
10(21.7 \%)\end{array}$ & 0.705 \\
\hline $\begin{array}{l}\text { Stage: } \\
\text { III } \\
\text { IV }\end{array}$ & $\begin{array}{l}10(22.2 \%) \\
35(77.8 \%)\end{array}$ & $\begin{array}{c}7(15.2 \%) \\
39(84.8 \%)\end{array}$ & 0.279 \\
\hline $\begin{array}{l}\text { metastatic sites: } \\
\text { Lymph nodes } \\
\text { Other lung and pleura } \\
\text { Liver } \\
\text { Bones } \\
\text { Adrenal glands }\end{array}$ & $\begin{array}{c}27(60 \%) \\
35(77.8 \%) \\
10(22.2 \%) \\
17(37.8 \%) \\
5(11.1 \%)\end{array}$ & $\begin{array}{c}30(65.2 \%) \\
32(69.6 \%) \\
10(21.7 \%) \\
20(43.5 \%) \\
7(15.2 \%)\end{array}$ & N.s.* \\
\hline $\begin{array}{l}\text { Histology: } \\
\text { Adenocarcinoma } \\
\text { Squamous cell carcinoma } \\
\text { Large Cell carcinoma } \\
\text { Undifferentiated }\end{array}$ & $\begin{array}{c}24(53.3 \%) \\
17(37.8 \%) \\
3(6.7 \%) \\
1(2.2 \%)\end{array}$ & $\begin{array}{l}25(54.3 \%) \\
15(32.6 \%) \\
6(13.0 \%)\end{array}$ & 0.087 \\
\hline $\begin{array}{l}\text { Histological Grade: } \\
\text { II } \\
\text { III }\end{array}$ & $\begin{array}{l}35(77.8 \%) \\
10(22.2 \%)\end{array}$ & $\begin{array}{c}32(69.6 \%) \\
14(30.46 \%)\end{array}$ & 0.258 \\
\hline
\end{tabular}

ECOG PS = Eastern Cooperative Oncology Group (ECOG) performance status

$\mathrm{GC}=$ gemcitabine-cisplatin, $\mathrm{GD}=$ gemcitabine-docetaxel

N.s. ${ }^{*}=$ no significant differences between metastatic sites distribution in the two groups

Table 2: Outcome of both arms.

\begin{tabular}{|c|c|c|c|}
\hline Item & $\begin{array}{c}\text { Arm 1 } \\
(\text { GC patients }=45)\end{array}$ & $\begin{array}{c}\text { Arm 2 } \\
\text { (GD patients=46) }\end{array}$ & $P$-value \\
\hline \multicolumn{4}{|l|}{ Response: No. (\%) } \\
\hline Partial response & $21(46.7 \%)$ & $20(43.5 \%)$ & \multirow{3}{*}{0.489} \\
\hline Stable disease & $11(26.7 \%)$ & $12(26.1 \%)$ & \\
\hline Progressive disease & $13(28.9 \%)$ & $14(30.4 \%)$ & \\
\hline \multicolumn{4}{|c|}{ Progression-free survival } \\
\hline Median (months) & 6.8 & 6.5 & \multirow{2}{*}{$0.772 *$} \\
\hline S.D (min-max) & $0.302(6.2087 .392-)$ & $0.472(5.575-7.425)$ & \\
\hline \multicolumn{4}{|l|}{ Overall survival } \\
\hline Median (months) & 8.9 & 8.5 & \multirow{2}{*}{$0.945^{*}$} \\
\hline S.D (min-max) & $0.674(7.580-10.220)$ & $0.421(7.647-9.326)$ & \\
\hline \multicolumn{4}{|c|}{$\mathrm{GC}=$ gemcitabine-cisplatin, $\mathrm{GD}=$ gemcitabine-docetaxel, $\mathrm{SD}=$ standard deviation } \\
\hline
\end{tabular}




Vol. 10 | No. 1-2 $2014 \quad$ Samy M. Al-Gizawy and Hanan G. Mostafa

Table 3: NCI-CTC grades 3/4 Toxicity of both Arms.

\begin{tabular}{lccc}
\hline Item & $\begin{array}{c}\text { Arm 1 } \\
\text { (GC patients= 45) } \\
\text { No.(\%) }\end{array}$ & $\begin{array}{c}\text { Arm 2 } \\
\text { (GD patients=46) } \\
\text { No.(\%) }\end{array}$ & P value \\
\hline Hematological: & & & 0.077 \\
Anaemia & $8(17.8)$ & $4(8.7)$ & 0.086 \\
Neutropenia & $19(42)$ & $11(24)$ & \\
Thrombocytopenia & $14(31)$ & $7(15.2)$ & $3(6.5)$ \\
Febrile neutropenia & $5(11)$ & & \\
Non-hematological: & & $4(8.7)$ & -- \\
Neurotoxicity & $2(4.4)$ & $3(6.5)$ & \\
Hepatotoxicity & $4(8.8)$ & $3(13)$ & \\
Fatigue & $5(11)$ & $5(10.9)$ & \\
Mucositis & $4(8.8)$ & $2(4.3)$ & - \\
Nausea \& Vomiting & $8(17.6)$ & - & \\
diarrhea & $3(6.7)$ & $1(2.2)$ & \\
renal & & & \\
\hline
\end{tabular}

NCI-CTC $=$ National Cancer Institute Common Toxicity Criteria version 2.0

$\mathrm{GC}=$ gemcitabine-cisplatin, $\mathrm{GD}=$ gemcitabin-docetaxel

\section{DISCUSSION}

The aim of the study was to compare the gemcitabinedocetaxel combination with cisplatin-gemcitabine regimen in patients with advanced or metastatic NSCLC in a phase III study.

There were no statistically significant differences in PFS and median OS between GD group and GC group (6.5 versus 6.8 months, $[P=0.772]$ and 8.5 versus 8.9 months, $[P=0.945]$ respectively). The response rates were also comparable; $46.7 \%$ for GC Arm versus $43.5 \%$ for GD Arm, $(P=0.489)$. In accordance with our results, a meta-analysis comparing the efficacy and toxicity of gemcitabine plus docetaxel (GD) with platinum-based doublet in patients with untreated advanced NSCLC, found that the efficacy was comparable between both regimens according to overall survival and 1-year survival. Although platinum-based regimen had an advantage in time to progression (TTP) and overall response rate (ORR), the advantage was lost when the two trials used sequential regimens were removed ${ }^{11}$.

In 2001, Georgoulias et al. ${ }^{12}$ performed a randomized multicentre trial to compare gemcitabine plus docetaxel with platinum-based doublet. They reported that DC (Docetaxel 100mg/m², day 1, Cisplatin $80 \mathrm{mg} / \mathrm{m}^{2}$, day 1) versus DG (Docetaxel $100 \mathrm{mg} / \mathrm{m}^{2}$, day 8; Gemcitabine $1100 \mathrm{mg} / \mathrm{m}^{2}$, days 1 and 8 ) had similar efficacy (response rate, $32.4 \%$ vs $30.2 \%$ ) and survival data (median OS 10 vs 9.5 months).

Georgoulias et al. ${ }^{13}$ also conducted another randomized phase III trial (413 patients) comparing Docetaxel plus Gemcitabine with Cisplatin plus
Vinorelbine (VC) with prophylactic G-CSF support. Overall response rates were $30 \%$ and $39.2 \%(P=$ 0.053 ) for the DG and VC arms, respectively. Median survival time was 9.0 and 9.7 months $(P=0.965)$ for the DG and VC arms, respectively. Pujol et al. ${ }^{14}$ also demonstrated that a non-cisplatin-based regimen was as effective as a cisplatin-based regimen. Their randomized phase III study compared the efficacy and safety of DG regimen (Docetaxel $85 \mathrm{mg} / \mathrm{m}^{2}$, day 8 plus Gemcitabine $1000 \mathrm{mg} / \mathrm{m}^{2}$, days 1 and 8) versus $\mathrm{VC}$ regimen (Vinorelbine $30 \mathrm{mg} / \mathrm{m}^{2}$, days 1,8 , and 15 plus Cisplatin $100 \mathrm{mg} / \mathrm{m}^{2}$, day 1). A total of 311 patients were enrolled. Objective response rates did not differ significantly (31\% for DG, 35.9\% for VC). Neither PFS nor overall survival differed significantly between the two arms (median PFS 4.2 and 4 months; median survival 11.1 and 9.6 months for DG and VC, respectively).

After that, seven other studies have evaluated the combination of Docetaxel and Gemcitabine in phase II trials. In their study of 133 patients, Katakami et $a l .{ }^{15}$ reported that $\mathrm{DG}$ (docetaxel $60 \mathrm{mg} / \mathrm{m}^{2}$, day $8+$ gemcitabine $800 \mathrm{mg} / \mathrm{m}^{2}$, days 1 and 8 , every 3 weeks) versus DC (docetaxel $60 \mathrm{mg} / \mathrm{m}^{2}$, day $1+$ cisplatin $80 \mathrm{mg} / \mathrm{m}^{2}$, day 1 , every 3 weeks) had similar efficacy (response rate, $27 \%$ vs $23.5 \%$ ) and survival data (median survival time, 13.7 months versus 11.4 months). In their study, $32.4 \%$ of patients in DC arm and $30.2 \%$ of patients in DG arm received gefitinib and this may explain the apparently better overall survival. Binder et al. ${ }^{16}$ tested gemcitabine $\left(900 \mathrm{mg} / \mathrm{m}^{2}\right)$ on days 1 and 8 , plus docetaxel $\left(75 \mathrm{mg} / \mathrm{m}^{2}\right)$ on day 1 every 3 weeks versus gemcitabine $\left(900 \mathrm{mg} / \mathrm{m}^{2}\right.$, days 1 and 8$)$ and cisplatin $\left(70 \mathrm{mg} / \mathrm{m}^{2}\right.$ day 1) for 3 cycles, followed by 3 cycles of docetaxel $\left(100 \mathrm{mg} / \mathrm{m}^{2}\right.$, day 1 every 3 weeks). ORR, TTP, and OS 


Vol. 10 | No. 1-2 2014

were $20.4 \%, 3.6$ months, 8.7 months respectively in DG arm versus $31.0 \%$, 5.2 months, 9.4 months, respectively in arm Cis-Gem+Doc $(P>0.05)$. Similarly, the other five phase II trials ${ }^{17-21}$ reported no statistical difference in survival between the two regimens.

With the exception of the better OS (13.7 months) reported by Katakami et al..$^{15}$, the median OS ( 8.5 months) of our patients is comparable to that reported in previous studies. However, the variance between the observed response rate $(43 \%)$ in our study and other studies ${ }^{12-21}$ can be attributed to using different GD regimens and small sample sizes.

Regarding toxicity, the aforementioned metaanalysis showed that GD induced less grade 3-4 nausea/ vomiting, anemia, neutropenia and febrile neutropenia. Grade 3-4 diarrhea, sensory neuropathy, fatigue and thrombocytopenia were comparable between the two groups ${ }^{11}$. Another meta-analysis to compare platinumbased with non-platinum-based chemotherapy in advanced non-small cell lung cancer reported similar results in favor of the non-platinum doublets ${ }^{22}$. These results are consistent with our findings reporting that GD was associated with a more favorable toxicity profile. Grade 3/4 anemia, leucopenia, neutropenia and thrombocytopenia were worse in the cisplatingemcitabine group. Consequently, the incidence of febrile neutropenia was also higher with GC than with GD. Moreover, the incidence of cisplatinrelated toxicities such as nausea and vomiting and nephrotoxicity were observed mainly with GC. On the other hand, grade 3 neurotoxicity was more frequent in GD arm as expected, due to the use of docetaxel. All these differences do not reach statistical significance due to small sample size.

There was also no difference in OS between the two treatment arms with regards the primary stratification factor of histology. Patients with non-squamous histology have similar OS after treatment with GD compared with GC. Previous studies have reported improved activity of platinum-based therapies in patients with adenocarcinoma compared with those with squamous tumor histology ${ }^{23,24}$. Further prospective studies evaluating the efficacy of docetaxel combinations in conjunction with molecular and genomic tumor analysis may be warranted.

In conclusion, the results presented in this study suggest that gemcitabine-docetaxel (GD) combination is equally active to standard cisplatin-gemcitabine (GC) regimen when used as first-line therapy in the treatment of patients with stage IIIB/IV NSCLC. The more favorable toxicity profile of GD supports its use as firstline chemotherapy, especially in patients who cannot tolerate cisplatin. However, the higher cost of the GD regimen is an issue that should be taken into account for the final therapeutic decision.

\section{REFERENCES}

1. Brambilla E, Travis WD. Lung cancer. In: Stewart BW, Wild CP, editors. World cancer report Lyon: World Health Organization; 2014. pp. 350-61.

2. McErlean A, Ginsberg MS. Epidemiology of lung cancer. Semin Roentgenol. 2011 Jul;46(3):173-7.

3. Pennell NA. Selection of chemotherapy for patients with advanced non-small cell lung cancer. Cleve Clin J Med. 2012 May;79(Electronic Suppl. 1):eS46-50.

4. Non-small Cell Lung Cancer Collaborative Group. Chemotherapy in non-small cell lung cancer: A metaanalysis using updated data on individual patients from 52 randomised clinical trials. BMJ. 1995 Oct. 7;311(7010):899-909.

5. NSCLC Meta-Analyses Collaborative Group. Chemotherapy in addition to supportive care improves survival in advanced non-small-cell lung cancer: A systematic review and meta-analysis of individual patient data from 16 randomized controlled trials. J Clin Oncol. 2008 Oct 1;26(28):4617-25.

6. Matsui K, Hirashima T, Nitta T, Kobayashi M, Ogata Y, Furukawa M, et al. A phase I/II study comparing regimen schedules of gemcitabine and docetaxel in Japanese patients with stage IIIB/IV non-small cell lung cancer. Jpn J Clin Oncol. 2005 Apr;35(4):181-7.

7. Yokoyama A, Nakai Y, Yoneda S, Kurita Y, Niitani H, Taguchi T. A late phase II study of LY188011 (Gemcitabine hydrochloride) in patients with non-small-cell lung cancer. Gemcitabine Cooperative Study Group B for Late Phase II. Gan To Kagaku Ryoho. 1996 Oct;23(12):1681-8.

8. Onoshi T, Watanabe K, Furuse K, Kurita Y, Sugiura T, Sato $\mathrm{K}$, et al. Late phase II study of RP56976 (docetaxel) in patients with non-small-cell lung cancer. Gan To Kagaku Ryoho. 1995;22:59-65.

9. Zoli W, Ricotti L, Dal Susino M, Barzanti F, Frassineti GL, Folli S, et al. Docetaxel and gemcitabine activity in NSCLC cell lines and in primary cultures from human lung cancer. Br J Cancer 1999 Oct;81(4):609-15.

10. Miller AB, Hoogstraten B, Staquet M, Winkler A. Reporting results of cancer treatment. Cancer 1981 Jan 1;47(1):207-14.

11. $\mathrm{Yu} Y, \mathrm{Xu} X, \mathrm{Du} Z$, Shi M. Non-platinum regimens of gemcitabine plus docetaxel versus platinum-based regimens in first-line treatment of advanced non-small cell lung cancer: A meta-analysis on 9 randomized controlled trials. Cancer Chemother Pharmacol. 2012 May;69(5):1265-75.

12. Georgoulias V, Papadakis E, Alexopoulos A, Tsiafaki $\mathrm{X}$, Rapti A, Veslemes M, et al. Platinum-based and nonplatinum-based chemotherapy in advanced non-small-cell lung cancer: A randomised multicentre trial. Lancet 2001 May 12;357(9267):1478-84. 
13. Georgoulias V, Ardavanis A, Tsiafaki X, Agelidou A, Mixalopoulou P, Anagnostopoulou $\mathrm{O}$, et al. Vinorelbine plus cisplatin versus docetaxel plus gemcitabine in advanced non-small-cell lung cancer: A phase III randomized trial. J Clin Oncol. 2005 May 1;23(13):2937-45.

14. Pujol JL, Breton JL, Gervais R, Rebattu P, Depierre A, Morère JF, et al. Gemcitabine-docetaxel versus cisplatinvinorelbine in advanced or metastatic non-small-cell lung cancer: A phase III study addressing the case for cisplatin. Ann Oncol. 2005 Apr;16(4):602-10.

15. Katakami N, Takiguchi Y, Yoshimori K, Isobe H, Bessho A, Yoshimura A, et al. Docetaxel in combination with either cisplatin or gemcitabine in unresectable non-small cell lung carcinoma: A randomized phase II study by the Japan Lung Cancer Cooperative Clinical Study Group. J Thorac Oncol. 2006 Jun;1(5):447-53.

16. Binder D, Schweisfurth H, Grah C, Schäper C, Temmesfeld Wollbrück B, Siebert G, et al. Docetaxel/gemcitabine or cisplatin/gemcitabine followed by docetaxel in the firstline treatment of patients with metastatic Non-Small Cell Lung Cancer (NSCLC): Results of a multicentre randomized phase II trial. Cancer Chemother Pharmacol. 2007 Jun;60(1):143-50.

17. Novello S, Falcone A, Crinò L, Rinaldi M, Nardi M, de Marinis F, et al. Randomised multicenter phase II study of two schedules of docetaxel and gemcitabine or cisplatin/ gemcitabine followed by docetaxel as first line treatment for advanced non-small cell lung cancer. Lung Cancer 2009 Dec;66(3):327-32.

18. Rubio JC, Vázquez S, Vázquez F, Amenedo M, Fírvida JL, Mel JR, et al. A phase II randomized trial of gemcitabinedocetaxel versus gemcitabine-cisplatin in patients with advanced non-small cell lung carcinoma. Cancer Chemother Pharmacol. 2009 Jul;64(2):379-84.
19. Casal J, Amenedo M, Mel JR, Antón LM, Rodríguez López $\mathrm{R}$, López López R, et al. Gemcitabine plus docetaxel as first-line chemotherapy in patients with advanced nonsmall cell lung cancer: A lung cancer Galician group phase II study. Cancer Chemother Pharmacol. 2007 Oct;60(5):725-32.

20. Kalmadi S, McNeill G, Davis M, Peereboom D, Adelstein D, Mekhail T. Phase II trial of weekly docetaxel and gemcitabine as first-line therapy for patients with advanced non-small cell lung cancer. Med Oncol. 2006;23(4):507-13.

21. Park SH, Hong J, Kim YS, Kim Y, Kyung SY, An CH, et al. Phase II trial of weekly docetaxel and gemcitabine for previously untreated, advanced non-small cell lung cancer. Lung Cancer 2008 Oct;62(1):72-7.

22. D'Addario G, Pintilie M, Leighl NB, Feld R, Cerny T, Shepherd FA. Platinum-based versus non-platinum-based chemotherapy in advanced non-small-cell lung cancer: A meta-analysis of the published literature. J Clin Oncol. 2005 May 1;23(13):2926-36.

23. Pimentel FL, von Pawel J, Martins RG, Novello S, Douillard J, O'Brien M, et al. Resource utilization by non-small cell lung cancer histology: Results from the randomized, phase III trial of pemetrexed/cisplatin versus gemcitabine/cisplatin. J Clin Oncol. 2008 May;26(15 Suppl.):Absrt. No. 8097.

24. Hida T, Okamoto I, Kashii T, Satouchi M, Ichinose Y, Katakami N, et al. Randomized phase III study of platinum-doublet chemotherapy followed by gefitinib versus continued platinum-doublet chemotherapy in patients (pts) with advanced Non-Small Cell Lung Cancer (NSCLC): Results of West Japan Thoracic Oncology Group trial (WJTOG 0203). J Clin Oncol. (Meeting Abstracts) 2008 May;26(15 Suppl.):Abstr. No. LBA8012. 